\title{
Middle molecules in severe community-acquired pneumonia
}

\author{
T Dumitras ${ }^{1}$, V Garbuz ${ }^{2,3^{*}}$, C Gutu-Bahov, S Matcovschi, I Camerzan , N Gurschi²,4 \\ From ESICM LIVES 2015 \\ Berlin, Germany. 3-7 October 2015
}

\section{Introduction}

In recent years there is a revival of interest to the plasma level of middle molecules which is the marker of activation of endogenous proteolysis and the expressiveness of endogenous intoxication syndrome.

\section{Objectives}

To examine the state of middle molecules (MM) in the blood plasma of patients with severe community-acquired pneumonia (CAP).

\section{Methods}

Retrospective analysis of 23 cases of severe CAP hospitalized in Critical Care Unit of Sfanta Treime Municipal Hospital, Chisinau, from October 2014 to February 2015. The measurements of level of the peptide substances belonging to a group of "middle molecules" (MM) using spectrophotometer were carried out and the results were compared to the levels of 11 healthy controls.

\section{Results}

Patients admitted had mean age of $62 \pm 1.2$ years, PORT classes IV-V and mean Pneumonia Severity Index score of $108.5 \pm 3.8$. In all patients on admission there was a high level of endogenous intoxication manifested by 1.8 times increasing levels of MM compared to the control group $(0.262 \pm 0.001$ versus $0.146 \pm 0.02$ optic units, $\mathrm{p}<0.05)$. There was a positive trend with a decline of MM on day 7 $-0.248 \pm 0.001$. No positive correlation was found between $\mathrm{MM}$ and other laboratory parameters with the exception of increased band neutrophils $(\mathrm{r}=0.71, \mathrm{p}<0.05)$. ICUmortality constituted $21.7 \%(5 / 23)$. In patients who died MM level was $0.438 \pm 0.002$ optic units, which was 3 times higher compared to the control group $(\mathrm{p}<0.05)$.

\footnotetext{
'State University of Medicine and Pharmacy 'Nicolae Testemitanu', Department of Anaesthesiology and Reanimatology Nr.2, Chisinau, Republic of Moldova

Full list of author information is available at the end of the article
}

\section{Conclusions}

Determining the plasma level of middle molecules can be used as an additional dynamic criterion of severity of endogenous intoxication in community-acquired pneumonia.
Authors' details

'State University of Medicine and Pharmacy 'Nicolae Testemitanu', Department of Internal Medicine, Chisinau, Republic of Moldova. 'State University of Medicine and Pharmacy 'Nicolae Testemitanu', Department of Anaesthesiology and Reanimatology Nr.2, Chisinau, Republic of Moldova. ${ }^{3}$ Sfanta Treime Municipal Hospital, Critical Care Unit, Chisinau, Republic of Moldova. ${ }^{4}$ Sfanta Treime Municipal Hospital, Department of Toxicology, Chisinau, Republic of Moldova.

Published: 1 October 2015

\section{References}

1. Makarevich A, et al: The effect of extracorporeal efferent detoxication methods inclusion in the severe community-acquired pneumonia treatment. Advances in Medical Science 2006, 51:73-87.

2. Nikolajchik W, et al: The method of detection of "middle molecules". Labor Work 1991, 10:13-8.

doi:10.1186/2197-425X-3-S1-A791

Cite this article as: Dumitras et al:: Middle molecules in severe community-acquired pneumonia. Intensive Care Medicine Experimental 2015 3(Suppl 1):A791.

\section{Submit your manuscript to a SpringerOpen ${ }^{\odot}$} journal and benefit from:

- Convenient online submission

- Rigorous peer review

- Immediate publication on acceptance

- Open access: articles freely available online

$\rightarrow$ High visibility within the field

Retaining the copyright to your article

Submit your next manuscript at $>$ springeropen.com

\section{SpringerOpen $^{\circ}$}

(c) 2015 Dumitras et al.; This is an Open Access article distributed under the terms of the Creative Commons Attribution License (http:// creativecommons.org/licenses/by/4.0), which permits unrestricted use, distribution, and reproduction in any medium, provided the original work is properly cited. 